building and equipment of an institute, provided the Government of India undertook its maintenance. A site was acquired in 1930, and the building erected adjacent to the Tropical School, which was opened in 1932. The work of the Institute is carried on in six sections, and a representative staff has been appointed under the directorship of Lieut. Col. A. D. Stewart, who is also the professor of hygiene. A description of the building is given, together with an account of the work of the sections, and of the research work that is in progress.

\section{Food Poisoning}

THE Ministry of Health has issued a memorandum on the steps to be taken by medical officers of health (outside London) in suspected cases of food poisoning (Memo. 188/Med.). The two classes of food poisoning are dealt with-contamination of food by poisonous chemicals and bacterial infections of food, which are far more frequent. Directions are given outlining the methods of investigating outbreaks, the collection of material for chemical or bacteriological examination, and method of packing and transmission to the Ministry, with hints on the chemical or bacterio. logical examination. In an appendix, a scheme is outlined for the routine inquiry into outbreaks of poisoning by meat foods, and in a second appendix valuable details are given for the isolation and identification of the bacteria (Salmonella) concerned in bacterial food poisoning.

\section{International Congress on Soil Science}

The papers presented to the third Intermational Congress on Soil Science, held recently at Oxford, embody work that is representative of most aspects of soil science; these are issued in two volumes (London: Thomas Murby and Co., 1935). The first volume contains those presented to the several commissions, and the second includes papers read at the plenary sessions, together with the address of the president, Sir John Russell. The papers are in English, French or German. The president, in his address, dealt with the contribution of soil science towards improving economic conditions, mentioning in particular the value of the surveying and mapping of soils as a preliminary to all schemes of agricultural development. As interesting examples of such contribution, those mentioned by Hardy, in his paper on "Some Aspects of Tropical Soils", may be quoted; these dealt more particularly with quantitative soil profile investigations. In the Caribbean region, for example, studies of this nature have rendered possible the exact definition of soil best adapted to the growth of several important orchard and field crops, and have made manifest certain soil factors that are definitely harmful to those crops. This aspect of soil work was dealt with by the commission on soil genesis, morphology and cartography and by that on the application of soil science to land amelioration.

No part of soil science stands to gain more from a Congress of this nature than that represented by those two commissions, since work in this field would lose much of its value without uniformity in methods of approach and expression of results. Studies on the composition and structure of the soil, divided for the purpose of the Congress into four commissions, namely, soil physics, soil chemistry, soil microbiology and soil fertility, reflect the progress that has been made in recent years in this aspect of soil work. Schofield made a contribution in which soil moisture relationships are regarded from a new point of view based on energy considerations, and introduced a scale to specify the degree of wetness or dryness of a soil ; it was shown that by carefully distinguishing wetting from drying conditions, a more rational interpretation could be applied to data on plant wilting and field moisture capacity.

\section{Cooke's Illustrations of British Fungi}

A MAGNIFICEnT series of eight volumes of "Illustrations of British Fungi" appeared towards the close of the last century. They were the work of Dr. M. C. Cooke, and served as a very pleasing and facile reference for naming the larger fungi. More recent advances in the scientific nomenclature of the Basidiomycetes, however, have shown that the names attached to the plates were not always correct. A great deal of confusion has resulted, and has somewhat diminished the usefulness of the work. Mr. A. A. Pearson has largely remedied this state of affairs, by publishing a modernised index to the "Illustrations" (Trans. Brit. Mycol. Soc., 20, Pt. 1, 33-95, Aug. 1935). This was originally based on notes prepared by Dr. Quelet, but Mr. Pearson also obtained the opinions of Prof. René Maire and Mr. Carleton Rea. These authorities concur upon a large number of species, but are by no means agreed upon others. The student of mycology will, however, be able to find the highest common factor between them where necessary, and will be able to use his Cooke's "Illustrations" again, with reasonable accuracy.

\section{Fossil Elephants in Eldorado}

A Notable discovery of the remains of the extinct Columbian elephant, one of the largest of elephants, is recorded from Eldorado, Oklahoma, by Science Service, Washington, D.C. The University of Oklahoma and Kansas State College have united in excavating certain mounds in which casual digging had revealed fossil bones, and the first results include seven skulls and many bones, tusks and teeth of the species referred to. The elephant remains range from those of mature individuals to young ones, five to seven years old. In addition to these remains, bones of extinct species of camel, horse and bison have been excavated. It appears that the area of the discoveries was an ancient water-hole which had a bottom of very soft mud in which the animals had become bogged.

\section{Guide to Statistics}

THE "Guide to Current Official Statistics of the United Kingdom", for 1934 (H.M. Stationery Office. 1s.), has recently been published. This guide, now in its thirteenth year, has become almost indispensable 